\title{
Pro-match literature and royal supremacy: The case of Michael Du Val's The Spanish English Rose (1622)
}

\author{
Leticia Álvarez Recio \\ Universidad de Sevilla
}

\begin{abstract}
In the years 1622-1623, at the climax of the negotiations for the Spanish-Match, King James enforced censorship on any works critical of his diplomatic policy and promoted the publication of texts that sided with his views on international relations, even though such writings may have sometimes gone beyond the propagandistic aims expected by the monarch. This is the case of Michael Du Val's The Spanish-English Rose (1622), a political tract elaborated within court circles to promote the Anglo-Spanish alliance. This article analyzes its role in producing an alternative to the religious and imperial discourse inherited from the Elizabethan age. It also considers the intertextual relations between Du Val's tract and other contemporary works in order to determine its part within the discursive network of the Anglican faith and political absolutism. The reasons why it may have exerted a negative influence on both the English and Spanish royal households are explored as well.
\end{abstract}

KEY WORDS: Spanish Match, pro-match literature, anti-match literature, political absolutism, Jacobean church.

Public interest in international affairs in the 1620 s was unprecedented. The beginning of the Thirty Years' War in 1618 had given rise to a news boom intended to satisfy the curiosity of the English, who now viewed domestic conflicts within a broader framework. The political and religious confrontations in Germany

$$
\text { Gederi } 22 \text { (2012: 7-27) }
$$

https:// doi.org/10.34136/sederi.2012.1 
reminded them of the recurrent Catholic threat - as perceived by them - and warned them against any possible alliance with the enemy. To many readers of news, the Spanish Match was just one more stratagem of international Catholicism, led by Spain against European Protestantism, and now embodied in the figures of Frederick and Elizabeth of Bohemia. ${ }^{1}$

The means by which news was circulated of news circulation were numerous and answered to the needs of different types of readers. By this time, both printed news and pamphlets had become the main source of information about international affairs. They had a small format, and were cheap and easy to carry, which made them accessible to a wide range of readers, including members of the gentry, and the professional, merchant and aristocratic classes. Scribal publication also participated in the professional production of news, and scribes shared the same taste for continental politics as the authors of printed texts (Bellany 2007:93). Moreover, the same people who produced political pamphlets and printed newsletters also produced commercial manuscript news for a more elitist public, and were thus involved in the same circulation channels (Baron 2001:44-53).

As in earlier periods, preachers often raised outcries against the monarch, and from 1618 to 1624 several clergymen encouraged their congregations to defend the Protestant cause against the Spanish Match. ${ }^{2}$ The fact that in August 1622 King James commanded the

\footnotetext{
${ }^{1}$ In 1618, James's son-in-law Frederick V had accepted the Bohemian crown after the rebellion of the Protestant estates against their Habsburg King - and later Emperor Ferdinand. The Palatinate question became then a major obstacle in the Stuart monarch's relations with Spain, which supported the Habsburg Empire. Defending a rebel could be risky as it could be used as an argument against the English King himself. This explains that James tried to secure the Spanish alliance with the Match in order to counteract Frederick's aggression and protect England from European struggle.

${ }^{2}$ See Thomas Taylor's A Mappe of Rome (1619), Thomas Gataker's A Sparke toward the Kindling of Sorrow for Sion (1621) and Thomas Jackson's Iudah must into Captiuitie (1622). Some of these critical preachers had influential patrons, such as Lord Kensington and the Secretary of State, Edward Conway, who protected them from punishment, but they were not allowed to publish their sermons. However, other preachers, including John Everard, Thomas Young, Thomas Winniffe, Mr Clayton, Richard Handes and Samuel Ward, could not escape punishment and were reprimanded for their criticism of James's policy towards Spain and the Palatinate (Fincham and Lake 1985:171-172).
} 
Archbishop of Canterbury to issue instructions to his clergy not to comment on affairs of state from the pulpit is striking, and shows the dangerous influence of this critical section of the Anglican clergy on public opinion (Abbot 1622:1-3).

These anti-Catholic and anti-Spanish prejudices were also prominent in literary works, mainly poetry, which made violent attacks on the Spanish marriage. ${ }^{3}$ Most of this poetry circulated in manuscript form, thus preventing censorship. As Thomas Cogswell underlines, "the safety of the 'underground' manuscripts allowed contemporaries to conduct a steady, often violent political debate" and their ability to reach a wide, socially and geographically varied audience made them close to a mass media market (1995:287; Bellany 2007:93, 109-110). Moreover, many of these poets were associated with the theatre, which also became a useful means for the discussion of contemporary affairs, thus increasing theatre attendance and the sales of printed playbooks. Fletcher and Massinger's Sir John Van Olden Barnavelt (1619), Middleton's Hengist, King of Kent (1615-1620) and A Game at Chess (1625), Dekker's The Noble Spanish Soldier (1622), and John Ford's The Welsh Ambassador (1623) are significant examples of this trend (Marshall 2000:145-181).

King James was obviously worried about the growing popular debate on his foreign policy, hence his need to control the contents of printed matter, which more than ever focused on politics. For this purpose, "A Proclamation against Excesse of Lauish and Licentious Speech of Matters of State" was issued on 24 December 1620 and republished on 26 July 1621 (Larkin and Hughes 1973-1982:519-521). Although some historians have underlined the state's effectiveness in pursuing those who published offensive material (Cogswell 1989:21), this seems to be only partly true as neither the authorizers nor the High Commission or the Stationers' Company had always maintained a consistent and regular control over printing; at times, they even disagreed with the King's views. In addition and according to Cyndia Clegg, "when censorship was employed propagandistically, the books concerned often remained in circulation or were suppressed only temporarily and returned to

3 "On the Princes Going to Spain" (Folger Library, V.a.418, fol. 48v); "On Mr Washington" (Folger Library, V.b.43, fol. 3); "An Elegie" (Beinecke Library, Osborn b197, 190-192); and "Illium Deplores" (Folger Library, V.a275, 11-12) (Cogswell 1989:46-48). 
circulation when the political moment passed" (2001:17-18, 59). The "Proclamation against Seditious, Popish, and Puritanicall Bookes and Pamphlets" issued on 15 August 1624 revealed the increasing number of offensive texts that were still circulating in London, and James's unsuccessful attempt to control them (Clegg 2005:298-299; Larkin and Hughes 1973-1982:599-600).

\section{II}

At the same time as anti-Spanish authors were writing against the Match, a parallel propaganda campaign was being launched by the state in order to counteract such critical attitudes. Some of these proSpanish works were accounts of Charles's arrival in Madrid in 1623, and described in detail the entertainments offered to the Prince on the occasion, but did not explicitly debate the advantages of the Spanish marriage. ${ }^{4}$ Other writings, however, were political tracts that developed a number of arguments about the benefits of the Match and, in doing so, questioned the binary discourse that had offered a prejudiced image of Spain in sixteenth-century England (Stradling 1623; Tisdale 1623; Garrard 1624). These works proposed an inclusive religious alternative that confronted the traditional English nationalistic views inherited from the Elizabethan period, but most of all they intervened in a wider discursive network in which the nature of royal authority was being discussed. Michael Du Val's The Spanish-English Rose is a particularly relevant example in this regard.

The Spanish-English Rose was entered in the Stationers' Register on 23 July 1622 (Arber 1950:76). The conditions for its publication did not seem to be favourable, though, as is inferred from a letter

\footnotetext{
${ }^{4}$ See, for instance, John Digby's A True Relation and Iournall, of the Manner of the Arrival, and Magnificent Entertainment Giuen to the High and Mighty Prince Charles, Prince of Great Britaine, by the King of Spaine in his Court at Madrid (1623) and A Continuation of a Former Relation Concerning the Entertainment, Giuen to the Prince his Highnesse by the King of Spaine in his Court at Madrid (1623); Juan Antonio de la Peña's A Relation of the Royall Festiuities and Juego de Cañas (a Turnament of Darting with Reedes after the Manner of Spaine) Made by the King of Spaine at Madrid, the 21 of August this Present Yeere, 1623. To Honour the Espousall Treaties of the Illustrious Prince of Wales, with the Lady Infanta Maria of Austria (1623); and Andres de Almansa y Mendoza's Two Royall Entertainments, lately Giuen to the Most Illustrious Prince Charles, Prince of Great Britaine, by the High and Mighty Philip the Fourth King of Spaine (1623).
} 
from Reverend Joseph Mead to a Sir Martin Stuteville dated 8 June 1622, in which Mead referred to the existence of a Latin edition of the text which had offended King James and whose open sale had been prohibited. He also mentions the problems the author had encountered in publishing the English edition of his tract (Nichols 1828:917-918)..$^{5}$ This may explain why the authorship of the text is not clear. According to The STC and The Consortium of European Research Libraries (id: cnpooo13827), Michael Du Val was probably a pseudonym, a possibility also considered by the author of the anonymous pamphlet Boanerges, who referred to him as a "fantastical man" (1624:29), thus implying that he might not exist. The author's need to hide his identity emphasizes the precarious situation of those who debated the Match even from conciliatory positions. The Spanish-English Rose may have been intended to enhance the advantages of the Anglo-Spanish marriage and reinforce the authority of the English monarch against contemporary dissident voices, but it contains some paradoxes and controversial points that reveal the writer's difficulty in satisfying all sides involved in the negotiations.

The Spanish-English Rose opens with a sophisticated emblematic frontispiece, and a set of poems in Latin, English and Spanish addressed to the royal couple; dedications to Gondomar, Charles, and Philip of Spain, which anticipate the encomiastic tone of the text itself, follow. The engraving shows Charles and the Infanta Maria joining hands before Jesus Christ, who blesses their union. Above them, a heart is held by two hands with a cloud and a garter at each end. The author explains the significance of the picture: "[...] The Hand|Is Royal FAITH, the Heart is CHRIST Above:|The Garter SYMBOL of the Peoples Love.|What can DISSEVER, What can ere DIVIDE, $\mid$ So many Bonds and all so surely tied?" (sig. b4r). ${ }^{6}$ The landscape behind the couple - countryside, on one hand, and seashore, on the other - may represent their respective countries and suggests the union of both nations through their alliance. Moreover, an idea of the balance of power is evoked by the symmetrical

\footnotetext{
${ }^{5}$ Joseph Mead (1586-1638) was a well-known Hebraist and biblical scholar. From 1619 to 1631 he wrote regularly to his friend Sir Martin Stuteville. These letters contained transcriptions of news pamphlets from London in which he reported and commented on the Thirty Years War and contemporary political affairs (Jue 2006:15).

${ }^{6}$ Spelling has been modernized by the author.
} 
arrangement of the scene, which includes both the Stuart and Spanish Habsburg coats of arms. The position of Jesus Christ in the middle clarifies any possible doubts about the Christian basis of the Match.

This same image had also appeared in a tract by Scipio Mirandula entitled Cynthia Coronata (ca. 1623). According to John Nichols, both texts, The Spanish-English Rose and Cynthia Coronata, could be found in Spain during Charles's visit to Madrid (1828:917918), which implies, first, that the Spanish court was aware of their contents, and second, that Du Val's frontispiece was well known in English court circles, as its reproduction in this other work proves. It may be also assumed that this illustration, far from being innovative, was part of a common propaganda campaign intended to shape a new royal image of the English monarchy in conjunction with its Spanish ally. The negative comments of some anti-Match writers on this image underline its controversial reception in less moderate circles, in disagreement with James's approach to Spain and Catholicism. In relation to this, the author of Boanerges interprets the engraving in a completely different sense: "I am glad that Christ is between them, for then sure he will never suffer them to join together, except God give her so much grace, which seldom happens to a Spaniard, to come out of Babylon, and not be partakers of her idolatries" (1624:29-30). Such was indeed the general opinion among radical Protestant authors who encouraged their readers to support God's cause against the Spanish enemy. Similarly, the anti-Spanish faction at court, far from being persuaded by $\mathrm{Du}$ Val, would have been enraged by his conciliatory views. The author's allusion to the book's circulation in Edinburgh also shows that it was not only restricted to English court circles.

The author, however, counteracts such attacks in his dedication, in which he expresses his concern about so much popular disagreement with James's policy and the negative image of the English monarch offered to foreign deputies by anti-Match literature (Du Val 1622: sigs. a1r-a1v, b1v-b2r). ${ }^{7}$ Instead, he highlights the

\footnotetext{
${ }^{7}$ Many of these authors employed anti-Spanish discourse to criticize James's attitude. One of the most popular pamphleteers in this trend was Thomas Scott, whose virulent attacks were well-known both in England and abroad. For some examples, see Scott $(1623: 5,22-26,27-28,33-36$; 1624a: sigs. b1r-v, b2v; 1624b:3, 5 7), or his controversial piece Vox Populi (1620).
} 
imperial - and thus, absolute and unchallenged - nature of English sovereignty, promoted here in connection with the myth of the Golden Age (1-2). Du Val implicitly refers to James's concern about Tacitus's growing influence on many English thinkers, who saw parallels between Imperial Rome and the Jacobean court with regard to corruption and deception (Salmon 1989:214-223; Tuck 1993:104119). By contrast, the author identifies with the King's views on the Roman Empire as a source of peace and civilization. ${ }^{8}$ However, the empire seems to require the union of both countries, and a key element in the traditional view of imperial England, her autonomy, is thus being called into question. In this sense, $\mathrm{Du}$ Val reconsiders the imperial discourse inherited from the Elizabethan period which justified opposition to Rome and Spain as a means of attaining colonial - and economic - power, as well as political independence.

In addition, the Golden Age myth is alluded to in relation to England's union with the Habsburg dynasty. Consequently, English national sentiments are invoked through an inclusive rhetoric that interprets Anglo-Spanish diplomacy in terms of cooperation rather than submission. Their mutual help in the context of an alliance is proposed as the only way to attain prosperity. Du Val's symbolic union of the Spanish pomegranate and the English rose works in the same direction, as both patriotic emblems here transcend their respective national boundaries in favour of this new imperial ideal. The fact that the pomegranate was part of Catherine of Aragon's coat of arms - incorporated into English heraldry after she married Henry VIII - creates a link with a historic past when Spain and England had previously been united. ${ }^{9}$

Similarly, the Golden Age myth justifies one of the main attributes in James's iconography: his image as a peace-maker inspiring peaceful foreign policy. In this respect, the monarch is compared to the Lebanon cedar and to King Solomon (2). Such references support James's indirect comparison to Jesus Christ,

\footnotetext{
${ }^{8}$ James himself had often employed such classical imagery, appearing in imperial dress in commemorative medals imitating ancient Roman coins, and he compared himself to Emperor Augustus, as a bringer of peace (Peck 1991:1-17; Stenhouse 2004:403).

${ }^{9}$ Images of both the pomegranate and the rose had featured in a pamphlet on the coronation of Henry VIII and Catherine of Aragon with similar significance (Hawes 1509).
} 
mainly in his role as defender of the Protestant faith and shelter for his subjects. In addition, the cedar was largely used by Solomon in the building of the Temple, which allows for a link with the King of Israel. ${ }^{10}$ Solomon's conciliatory attitude is preferred to King David's warlike measures (6), thus contradicting anti-Spanish pamphleteers, who often chose David when they suggested that the English sovereign should fight Spain. Here, their belligerent mood is silenced, and their threatening tone is replaced by a more merciful image of God - and by extension, of the monarch - as a promoter of repentance. Indeed, this was a recurrent theme in some other contemporary tracts and sermons intended to promote more tolerant attitudes to religious differences. Many of them proposed God's infinite mercy as a model good Christians must follow (Harris 1622:24, 28-29; Hayward 1623; Stradling 1623:12-13; Thomas 1622:52; Warburton 1623:34), an opinion shared by Du Val and the King himself, who in his work A Meditation Vpon the 27.28.29 Verses the XXVII. Chapter of Saint Matthew (1620) had declared that "a King should never punish, but with a weeping eye" (Sommerville 1994:249). ${ }^{11}$

In addition, Solomon's idolatry, often used to discourage a Catholic match, is reinterpreted. Du Val does not blame Solomon's Egyptian wife but his other women for his idolatry, stressing the fact that he repented soon afterwards. In his view, God's punishment was an act of mercy, not of revenge (63). By pointing to Solomon, and to David's sinful but contrite behaviour, Du Val re-appropriates both biblical characters and endows them with new meanings that are alien to previous, more radical Protestant readings. Nevertheless, the question of Solomon's idolatry is not fully resolved, and this kind of argument would have most probably given rise to some anxiety among many Englishmen concerned about Charles's potential conversion to Catholicism after his journey to Spain.

\footnotetext{
${ }^{10}$ Comparisons between English monarchs and royal figures of the Old Testament mainly, David and Solomon - had been common since the reign of Henry VIII as they helped justify the monarchs' religious authority in terms of sacerdotium - the power to order religion and punish dissenters. Thus, Du Val follows a long tradition that invested English monarchs with the powers of imperium - according to which, royal authority could not be contested- and sacerdotium, which pointed to the sovereign's duty to defend the true doctrine (Prior 2005:862, 865-866, 883).

${ }^{11}$ Spelling has been modernized by the author.
} 
These apparent contradictions are, nonetheless, blurred by a hyperbolic description of James as the embodiment of princely Christian virtues (3-8). A redundant use of superlatives sets him above all the monarchs of Europe (3), while his imperial office and his claim of universal rights on the continent are portrayed as lacking any colonial ambitions; instead, James is presented as committed to bringing peace to all European nations (8-10). However, this view of his involvement in the welfare of other countries contradicts his alleged passivity towards Frederick and Elizabeth of Bohemia, which had been widely criticized in antiSpanish literature. Neither is mentioned, and instead, the German war is shown as a disaster that could still be prevented if new attitudes were adopted (24-25). A conciliatory policy, rather than James's support to the Elector Palatine, is offered as the only guarantee to safeguard James's children and subjects.

In this context, an Anglo-Spanish coalition is proposed as the model other European nations should adopt to promote harmony on the continent. Du Val insists on congenial and political links among European rulers and believes that their divisions are easy to overcome by merely appealing to family union. In fact, the same proposal had been considered by King James in his tract The PeaceMaker: "If the members of a natural body, by concord assist one another; if the politic members of a kingdom help one another, and by it support itself; why shall not the Monarchal bodies of many kingdoms, be one mutual Christendom" (1621: sig. B1v). ${ }^{12}$ In this way, the House of Austria's network of royal connections to most European powers is shown as the main reason for the Spanish Match, portrayed as a necessary instrument to put an end to international dissension (Du Val 1622:20). Nevertheless, the author's description of the military and commercial benefits England would enjoy thanks to her alliance with Spain questions James's altruistic and uninterested attitude (25-27).

In any case, James is described as mirroring God in the preservation of peace, which is considered the main responsibility of a Christian king; thus, a reference to the theory of order, the basis of

\footnotetext{
${ }^{12}$ All further quotations are taken from this edition.
} 
divine-right absolutism, ${ }^{13}$ is introduced, paraphrasing James's own opinions on the subject:

The state of Monarchy is the supremest thing upon earth. For Kings are not only Gods Lieutenants upon earth, and sit upon Gods throne, but even by God himself they are called Gods [...] Kings are justly called Gods, for that they exercise a manner of resemblance of Divine power upon earth [...] And to the King is due both the affection of the soule, and the service of the body of his subjects. (James I 1609: sigs. A4v-Bir) ${ }^{14}$

Hence, his peaceful policy endows his actions and decisions with a clear divine nature. He is only answerable to God for the exercise of his office, which deflects any attack on his rule. By extension, such critical voices which could disrupt the status quo are denounced as Satanic, acting against their nation's good and God's will (Du Val 1622:67).

Such criticism of James's opponents is reinforced through a defence of his absolute power: he is depicted as a primum mobile directing his subjects' actions and protecting them from disorder and ruin (72). The idea of mutual collaboration evoked by the body metaphor in many anti-Spanish pamphlets is now reversed to promote a sense of order, necessary for the preservation of the establishment. Indeed, Du Val paraphrases James's words in The Trew Law of Free Monarchies (1598, 1603), in which he had promoted his subjects' obedience in the following terms: "The head cares for the body, so doeth the King for his people. As the discourse and direction flowes from the head, and the execution according thereunto belongs to the rest of the members, euery one according to their office" (Sommerville 1994:76-77). Here King James and Du Val echo the early modern interpretation of the Roman theory of monarchy, according to which all members of the commonwealth should act in relation to hierarchy and status. In turn, the Roman prince's protection frees, rather than enslaves, them. The King's

\footnotetext{
${ }^{13}$ This theory justified the monarch's discretionary authority. According to Weston and Renfrow, "the raison d'etre of that authority was the conviction that the king as sovereign governor [and God's vicar] was possessed of a reserve of power with which to govern his kingdom and secure the public welfare" (2003:17, 21-22).

${ }^{14}$ All further quotations are taken from this edition. For similar examples in other contemporary texts, see Stradling (1623:6); Thomas (1622:124-128); and Warburton $(1623: 48,51,53)$.
} 
paternal care for his subjects is turned into a vehicle of freedom, which remains closely associated with order and obedience (Stacey 2007). ${ }^{15} \mathrm{Du}$ Val makes use of the same figurative language as James, who alludes to the relation between sovereigns and subjects as follows:

As the Fathers chief joy ought to be in procuring his children's welfare, rejoicing at their weal, sorrowing and pitying at their evil, to hazard for their safety, travel for their rest, wake for their sleep; and in a word, to think that his earthly felicity and life stands and lives more in them, nor in himself; so ought a good Prince think of his people. As to the other branch of this mutual and reciprocal band, is the duty and allegiance that the Lieges owe to their King. (Sommerville 1994:65-66)

According to Johann Sommerville, the description of the monarch as the nation's father was common in patriarchal theories of royal authority in Early Modern Europe. Many absolutist thinkers used this analogy to defend the divine nature of kings and the fact that political societies were not self-governing democracies - as many common-law minds believed - but absolute monarchies governed by a king and father (1994:29-30; 1991). In this sense, Du Val's treatise is not merely an apology of the Spanish Match, but participates in contemporary debates on different models of government siding with absolutist tendencies which began to prevail in most European monarchies at this time.

$\mathrm{Du}$ Val's insistence on the motif of Arcana Imperii (the secrets of rule or mysteries of the state) works in the same way. According to this principle, subjects had no right to question a monarch's decisions, as they were inscrutable. In contrast to the rhetoric of counsel, which had been largely used by anti-Spanish authors to justify their writings, ${ }^{16}$ the defenders of Arcana Imperii discouraged

\footnotetext{
${ }^{15}$ The Roman theory and the theory of order were deeply interrelated to support the monarch's absolute power. In Lewis and Ibbetson's opinion, the Roman prince was not subject to the law, his sovereignty being independent of the community. He was "an arbiter of life and death who wields executive power over [...] [those] whom he rules [...] a trustee required to render ratio to God for persons placed in his hands." His rule was both iure divino and naturale as "it was natural for the people to submit to the rule of those placed in authority over them" (Lewis \& Ibbetson 2007:77-78, 144, 147).

${ }^{16}$ This allowed for a degree of public debate about government policy. Thus, counsel was both a right and a duty of a good citizen attempting at the general welfare
} 
such practices, regarding them as rebellious actions against the monarchy (Stradling 1623:6, 26, 32-33; Thomas 1622:119; Tisdale 1623:10). ${ }^{17}$ The author identifies those attitudes with the opponents to the Spanish Match (52-53), counteracting their main arguments with the intention of discrediting them. In doing so, he deconstructs the anti-Spanish discourse inherited from the sixteenth century and questions, first, the traditional stereotype of the Spaniard, and second, conventional interpretations of key dates in English Protestant mythology: ${ }^{18}$

But they were Anciently your Dear and Honourable Friends, and never perhaps your Dishonourable Enemies. For though in the year 88 They came against you in Hostile manner, with a Mighty Navy: Yet did they not that, till they were first provoked by Grievous and Intolerable Injuries [...] By how many Robberies and Piracies were the Spaniards in those days from time to time, first Vexed by the English? [...] To say nothing of the Frequent and continual Auxiliary Forces afforded to the Rebellious Hollanders for so many years together against their Lawful and undoubted sovereign. (53-54)

Hence, Elizabethan anti-Catholicism, still a prevailing attitude among many disaffected English Protestants, is challenged. The reference to England's past support to Holland may remind readers of a similar situation when the Bohemian king had rebelled against Emperor Ferdinand. In both cases, a confessional foreign policy

(McDiarmid 2007:22). This view on counsel had been a maxim in sixteenth-century republican theories on citizenship and began to be employed in the 1610s-1620s by those critical of James's policies.

17 The King had addressed those critics in similar terms in a poem he wrote in 16221623: "You cannot judge what's truely mine, | Who see no farther then the rine.|Kings walke the heavenly milky-waye, | But you in by-paths goe astray. | God and King doe pace together,|But vulgar wander light as feather.|I should be sorry you should see|My actions, before they bee|Brought to the full of my desires:|God above all men, kings inspires. |Hold you the publick beaten way, |Wander at kings and them obey" (James I 1622/1623:143).

${ }^{18}$ Such anti-Catholic and anti-Spanish bias had been recurrent in Elizabethan England at a discursive level, which on many occasions had justified and promoted concrete action against Spain. However, it should not be forgotten that Anglo-Spanish cultural relations had been extensive since the late Middle Ages. English Elizabethans had also been sensitive to Spanish literature - mainly, lyrics, romances and plays, as well as works on history, science, religion and overseas expansion (Bouza 2007:58-60; Thompson 2006). Thus, the English view of Spain in the late sixteenth century cannot be reduced to the monolithic binary rhetoric of official Protestantism. 
against other European powers is neglected, while radical nationalistic discourse is dismissed as senseless and dangerous to England's interests.

In addition, the Spanish are described as courteous, moderate and honest, and not different from the English. Spain is portrayed as a nation of "Great and Glorious Emperors," "valiant and Renowned Captains," and "innumerable Wise and Learned Doctors and Professors," a pattern of imperial government, military glory and wisdom (31). This complimenting of Spain's colonial power could have been distressing to some readers, who might have been upset about the idea of Spanish supremacy. In order to prevent any such fears, Du Val balances laudatory descriptions of Spain with similar praise of England's imperial identity (32-34). In any case, there is a clear tendency to show similarities between both countries, avoiding any xenophobic prejudices.

Despite these attempts to temper anti-Spanish sentiment, however, one of the main obstacles to dynastic union still remained, and was not expected to be resolved. The different religions of both countries were a significant diplomatic problem, seriously affected by Spain's misguided belief that Charles would eventually convert to Catholicism. For Du Val, the Prince's change of religion was out of the question, and so he tried to convince his coreligionists of its impossibility by eulogizing the strength of the English Church and pointing to the Infanta's weak female nature to justify her lack of influence on the English heir. Rather, he argues, "It is Much More Probable, That the Prince being Furnished with So Many GREAT Helps and Means, Should Draw His Royal Spouse to His Religion" (74). ${ }^{19}$ As a result, diversity of religion is not shown as a potential source of division for the couple but as an element that may enrich their union (75).

\footnotetext{
${ }^{19}$ For a similar argument see Garrard (1624:63-64). These opinions contrast with those of some less moderate Protestants who feared a general conversion of the country to Catholicism: "If the marriage go forward they will take the more heart and greater encouragement, no small number of subjects want teaching, and so are they more easily shaken. [...] The worst is yet, that there will be party children: for the mother will give herself no rest till she have [nursed?] some of them in her own religion, which would make the way very plain \& easy for a change, because the head once corrupted, the infection will in short time spread itself over the whole body, and true religion is unsociable to sort itself with false worship, and will soon forsake his dwelling place" (Wood 1623:9). Spelling has been modernized by the author.
} 
This defence of the Protestant faith may well have been the reason for the confusion caused by Du Val's work in Spain. In fact, a copy of the text had reached Madrid soon after its publication in England. F. Francisco de Jesús, court preacher to King Philip III, describes reactions to the tract:

It was altogether unreasonable by anyone to suppose that, even if this book could have been published without the knowledge of the King of Great Britain, it could have been spread abroad so publicly as it was, both at home and abroad, without his being aware of it. Considering therefore, the particular attention which he always paid to things of this kind, so that it would be an insult to suppose that he would do nothing without a special object, who could avoid being startled and frightened by the intentions which were disclosed by these facts? And by this occurrence, and by the urgency used by all who had to do with the negotiations, the confusion was greatly increased. (Gardiner 1869:187)

As can be inferred from the preacher's words, these conciliatory views only contented the moderate faction at the English court, without satisfying the Spanish. The propaganda campaign organized by the pro-Spanish circles at James's court not only intended to persuade those factions critical of the Match, but also the Spanish authorities, who considered Charles' conversion a basic requirement. This may also explain King James's alleged disagreement with some of the content of Du Val's treatise, as it may have clashed with his amiable relations with Spain by arousing suspicion at the Spanish court. Although the work was intended for English readers, its rapid circulation abroad would have increased the confusion, mainly in matters of faith, of a non-coreligionist audience.

However, far from keeping quiet about the controversial issue of conversion, $\mathrm{Du} \mathrm{Val} \mathrm{insists} \mathrm{on} \mathrm{portraying} \mathrm{inter-religious} \mathrm{marriage}$ as a model to be followed. He quotes from Saint Jerome's and Saint Augustine's writings to confirm the frequent practice of marriage among people from different religions in the Primitive Church (59), and gives a large succession of biblical examples (59-64). By alluding to these sources, he defends the Match from accusations of irreligion and challenges its detractors with the possibility of divine punishment. Instead, he denies that Charles's marriage possessed any ungodly stain, and describes it as blessed and dignified by God.

In addition, the author's list of precedents for inter-religious marriage in England and Europe deprives the Spanish Match of its 
alleged novelty and naturalizes it as a common practice among European dynasties (57-59). Among a number of examples, he includes Catherine of Aragon's marriage to Henry VIII, as well as Philip of Spain and Mary Tudor's union. Both of these might seem questionable examples to support his argument: Mary Tudor's marriage had been a recurrent leitmotif in anti-Catholic and antiSpanish propaganda for over seventy years and had been considered a backward step in England's autonomy; and the reference to Catherine of Aragon might create some uneasiness among those nostalgic for Elizabeth I's reign, as it questioned Elizabeth's relevant position in English Protestant discourse. But Du Val only cites them as examples; he does not include any further commentary and seems unwilling to highlight their presence. Moreover, and despite the fears such references may generate, he seems to be keen on rewriting English Protestant history, its icons and prejudices.

In any case, his defence of inter-religious royal households does not extend to the English commonwealth, although some apology for religious toleration is implied in favour of stability and order. In relation to this, $\mathrm{Du}$ Val dismisses religious persecution as useless and defends persuasion as the most common way to promote conversion to the Anglican Church (75-76). Hence, he responds to the demands of anti-Match writers for a stricter application of penal laws against Catholics, and justifies James's leniency towards them over the previous few years.

Theological controversy is discouraged as disruptive, and a similar attitude is demanded from the Anglican clergy, which is partly blamed for dissensions within the Church of England and the social unrest against Spain. The attacks of some contemporary preachers on the Spanish Match are therefore considered unchristian because of their dangerous capacity to mobilize their brethren against the status quo. Here Du Val echoes King James's Speach in the Starre-Chamber (1616), in which he had affirmed that "It is the Kings Office to protect and settle the trew interpretation of the Law of God within his Dominions: and it is the Iudges Office to interpret the Law of the King, whereto themselues are also subiect" (Sommerville 1994:206). The same ideas appear in works by other authors, such as Roger Tisdale and John Stradling, who suggest that the monarch should exert a more rigid control over those Englishmen who challenge his authority. Surprisingly, these writers criticise James's 
leniency towards his detractors and observe Catholics with more indulgent eyes while transferring the focus to critical or less moderate Protestants. The publication of their works one year after The Spanish-English Rose, when the Spanish Match was supposed to be imminent, may explain their disapproval of the King's indulgent behaviour (Stradling 1623:11, 19, 23; Tisdale 1623:21). Du Val, instead, tries to be more cautious and does not comment on James's policy on this matter, though he rejects radical speech and claims a middle way for the Church of England, calling for it to maintain a perfect balance.

Thus nationalist views on religion are challenged in favour of a more international idea of Christianity, not limited to any single country or based on dual Calvinistic perspectives. Such transnational commitment allows for a general call for a Christian union against the Turk, portrayed as the epitome of the "other" against whom all should join arms. Providential rhetoric is employed to justify war against them, while similar arguments of necessity, often used by anti-Catholic authors, now work to validate belligerent attitudes against the Ottoman Empire (78-85). This last point, also present in other writings of the period (Stradling 1623:20-21; Warburton 1623:50), had been defended long before by King James, who in his poem Lepanto (repr. 1603), celebrating Spain's victory over the Turk in 1571, had revived the same idea of a Respublica Christiana.

As in these other writings, $\mathrm{Du}$ Val's defence of selective violence calls into question his previous apology of peace and reveals a manifold use of religious rhetoric. His appeal to a union suggests that the context for this kind of language and its purpose to promote unity out of internal dissension - is always the same, and contributes to disclose the artificial basis of this type of discourse. An ecumenical view of Christendom is evoked then in order to do away with the religious differences generated by the Reformation. Protestant Churches are indirectly portrayed as responsible for Christian division, and a more conciliatory attitude among Christians is suggested as the only way to solve political, religious and military problems. 


\section{III}

The Spanish-English Rose ends with a view of prospective harmony in the near future. The Spanish Match is perceived as the beginning of a new era that would finally restore the Golden Age in Charles's reign. In addition, a sense of continuity and hope is evoked to forestall fear of change, while encouraging popular support and obedience to the Stuart king and his heir. As a result, England's prosperity is presented as being dependant on international alliances, while a new concept of Englishness opposes sixteenth-century views on England's responsibility to European Protestantism. In this way, while anti-Spanish writers tried to revive Elizabethan confessional views on war and diplomacy, Du Val and other moderate authors began to progressively distance themselves from Calvinist theology in favour of a more inclusive ecclesiastical model. Earlier discourses against Spain and English Catholics are challenged, first by dissociating one figure from the other - there is not a single reference to Spain's relations with English recusants - and secondly, by challenging their stereotypes and exposing their artificial nature.

The Spanish-English Rose thus contributes to the production of an alternative religious and imperial discourse within a discursive network in which moderate Protestant authors tried to re-elaborate the main lines of England's national religion in accordance with the King's views on his regal authority. In fact, Du Val and other proSpanish writers not only supported their sovereign's messages on royal policy, but also presented their texts as extensions of James's royal power. Hence, by paraphrasing the sovereign's words, they responded to contemporary demands for more interactive types of government while participating, insofar as they could, according to the restrictions laid down by James.

$\mathrm{Du}$ Val's attempts to accommodate his text to this new diplomatic scenario was not, in fact, successful, as the negative reception of his work by King James and the Spanish court makes clear. Such negative readings point to Du Val's failure - and the failure of both Spanish and English diplomats - to reconcile each country's requirements for the Spanish Match; but above all they emphasize James's unwillingness to allow anyone to discuss the English heir's possible conversion to Catholicism, fearing that it would interfere with the monarch's plans towards Spain. Despite Du Val's efforts to be more cautious and self-restrictive than other 
contemporary pro-Match writers, The Spanish-English Rose could not avoid attracting some restrictions upon publication. However, its distribution in England, Scotland and abroad underlines the English monarch's inability to control debate on his foreign policy, even when it was sympathetic to the King's policy. The problems that the circulation and reception of this tract created exemplify the practical impossibility of writing, printing and spreading ideas in favour of absolutist regal power without challenging one main premise: that absolute authority was not open to debate. Hence, Du Val employs official political language quite subtly to, indirectly, reveal its limitations.

\section{References}

Abbot, George 1622. The Coppie of a Letter Sent from my Lords Grace of Canterburie Shewing the Reasons which Induced the Kings Maiestie to Prescribe Directions for Preachers. Oxford: J. Lichfield and J. Short. ESTC citation no 993071.

Anon 1624. Boanerges, or the Humble Supplication of the Ministers of Scotland to the High Court of Parliament in England. Edinburgh: s.n. ESTC citation no: S102729.

Arber, Edward 1950. A Transcript of the Registers of the Company of Stationers in London: 1554-1640. Vol. 4. Gloucester: Peter Smith.

Baron, Sabrina A. 2001. "The Guises of Dissemination in Early SeventeenthCentury England." Eds. Brendan Dooley and Sabrina Baron. The Politics of Information in Early Modern Europe. London \& New York: Routledge: 41-56.

Bellany, Alastair 2007. The Politics of Court Scandal in Early Modern England: News Culture and the Overbury Affair, 1603-1660. Cambridge: Cambridge University Press.

Bouza, Fernando ed. 2007. Anglo-Hispana. Cinco siglos de autores, editores y lectores entre España y el Reino Unido. Five Centuries of Authors, Publishers and Readers between Spain and the United Kingdom. Trans. Jenny Dodman. Madrid: Ministerio de Cultura.

Clegg, Cyndia Susan 2001. Press Censorship in Jacobean England. Port Chester, NY: Cambridge University Press.

2005. "Checking the Father: Anxious Paternity and Jacobean Press Censorship." Ed. Douglas Brooks. Printing and Parenting in Early Modern England. Aldershot: Ashgate: 291-302. 
Cogswell, Thomas 1989. The Blessed Revolution. English Politics and the Coming of War, 1621-1624. Cambridge: Cambridge University Press.

— 1995. "Underground Verse and the Transformation of Early Stuart Political Culture." Eds. Susan D. Amussen and Mark A. Kishlansky. Political Culture and Cultural Politics in Early Modern Europe. Manchester \& New York: Manchester University Press: 277-300.

Du Val, Michael 1622. Rosa Hispani-Anglica seu Malum Punicum Angl'Hispanicum Domini Benedictio Ditat. London: Eliot's Court Press. ESTC citation no: S100010.

Fincham, Kenneth and Peter Lake 1985. "The Ecclesiastical Policy of James I." Journal of British Studies 24: 169-207.

Gardiner, Samuel R. ed. 1869. Narrative of the Spanish Marriage Treaty. London: Camden Society.

Garrard, Edmund 1624. The Countrie Gentleman Moderator Collections of such Intermarriages, as Haue Beene betweene the Two Royall Lines of England and Spaine, since the Conquest: with a Short View of the Stories of the Liues of those Princes. London: Edward All-de. ESTC citation no: S10286o.

Harris, Robert 1622. Gods Goodnes and Mercy Layd Open in a Sermon, Preached at Pauls-Crosse on the Last of Iune. 1622. London: Iohn Davvson. ESTC citation no: S103797.

Hawes, Stephen 1509. A Ioyfull Medytacyon to all Englonde of the Coronacyon of our moost Naturall Souerayne Lorde Kynge Henry the Eyght. London: Wynkyn de Worde. ESTC citation no: S109508.

Hayward, John Sir 1623. Christs Prayer opon the Crosse for his Enemies Father Forgiue them, for they Know not What they Doe. London: Iohn Bill. ESTC citation no: S122571.

James I, King of England 16o9. The Kings Maiesties Speach to the Lords and Commons of this Present Parliament at White-Hall, on Wednesday the xxj of March. Anno Dom. 1609. London: Robert Barker, Printer to the Kings Most Excellent Maiestie. ESTC citation no: $\mathrm{S}_{473635 .}$

1621. The Peace-Maker: or, Great Brittaines Blessing. London: Iohn Beale. ESTC citation no: S93341.

1622/1623. "His Maiesties Answere unto a Libell." Eds. Neil Rhodes, Jennifer Richards and Joseph Marshall. King James VI and I. Selected Writings. Aldershot: Ashgate: 143-148.

Jue, Jeffrey K. 2006. Heaven Upon Earth. Joseph Mede (1586-1638) and the Legacy of Millenarianism. Dordrecht: Springer.

Larkin, James F. and Paul L. Hughes eds. 1973-1982. Stuart Royal Proclamations. Royal Proclamations of James I, 1603-1625. Vol. 1. Oxford: Clarendon Press. 
Lewis, A. D. E. and David J. Ibbetson 2007 (1994). The Roman Law Tradition. Cambridge: Cambridge University Press.

Marshall, Tristan 2000. Theatre and Empire: Great Britain on the London Stage under James VI and I. Manchester: Manchester University Press.

McDiarmid, John F. ed. 2007. The Monarchical Republic of Early Modern England. Aldershot: Ashgate.

Nichols, John 1828. The Progresses, Processions, and Magnificent Festivities of King James the First, his Royal Consort, Family and Court. Vol. 4. London: John B. Nichols, Printer to the Society of Antiquaries.

Peck, Linda Levy ed. 1991. The Mental World of the Jacobean Court. Cambridge: Cambridge University Press.

Prior, Charles W. A. 2005. "Ecclesiology and Political Thought in England, 1580-c. 1630." Historical Journal 48: 855-884.

Salmon, J. H. M. 1989. "Stoicism and the Roman Example: Seneca and Tacitus in Jacobean England." Journal of the History of Ideas 50/2: 199-225.

Scott, Thomas 1620. Vox Populi, or Newes from Spayne Translated According to the Spanish Coppie; Which May Serve to Forwarn both England and the Vnited Provinces How Farre to Trust to Spanish Pretences. London: s.n. ESTC citation no: S117014.

— 1623. An Experimentall Discoverie of Spanish Practices. [London?]: s.n. ESTC citation no: 33785 .

- 1624a. Certaine Reasons and Arguments of Policie, Why the King of England Should Hereafter Giue Over All Further Treatie, and Enter into Warre with the Spaniard. London: s.n. ESTC citation no: S118312.

1624b. The Spaniards Perpetuall Designes to an Vniuersall Monarchie. London: s.n. ESTC citation no: Si16966.

Sharpe, Kevin 1994. “The King's Writ: Royal Authors and Royal Authority in Early Modern England." Eds. Kevin Sharpe and Peter Lake. Culture and Politics in Early Stuart England. London: Macmillan: 117-138.

Sommerville, Johann P. 1991. "Absolutism and Royalism." Ed. J. H. Burns. The Cambridge History of Political Thought 1450-1700. Cambridge: Cambridge University Press: 347-373.

— ed. 1994. King James VI and I. Political Writings. Cambridge: Cambridge University Press.

Stacey, Peter 2007. Roman Monarchy and the Renaissance Prince. Cambridge: Cambridge University Press.

Stenhouse, William 2004. "Thomas Dempster, Royal Historian to James I, and Classical Scholarship in Early Stuart England." The Sixteenth Century Journal 35/2: 395-410. 


$$
\text { (G) ederi } 22 \text { (2012) }
$$

Stradling, John Sir 1623. Beati Pacifici a Diuine Poem. Written to the Kings Most Excellent Maiestie. London: Felix Kingston for the Company of Stationers. ESTC Citation no: S117913.

Thomas, Adams 1622. Eirenopolis. London: Aug. Matthewes. ESTC citation no: S115261.

Thompson, I. A. A. 2006. "Aspectos del hispanismo inglés y la coyuntura internacional en los tiempos modernos (siglos XVI-XVIII)." Obradoiro de historia moderna 15: 9-28.

Tisdale, Roger 1623. Pax Vobis, or, VVits Changes Tuned in a Latine Hexameter of Peace. London: G. Eld and M. Flesher. ESTC citation no: S118444.

Tuck, Richard 1993. Philosophy and Government 1572-1651. Cambridge: Cambridge University Press.

Warburton, George 1623. King Melchizedech. London: Printed Bonham Norton and Iohn Bill. ESTC Citation no: S119448.

Weston, Corinne Comsock and Janelle Renfrow Greenberg 2003. Subjects and Sovereigns: The Grand Controversy over Legal Sovereignty in Stuart England. Cambridge: Cambridge University Press.

Wood, William 1623. Considerations upon the Treaty of Marriage between England and Spain. The Netherlands?: s.n. ESTC citation no: S113665.

How to cite this article:

Álvarez Recio, Leticia. "Pro-match literature and royal supremacy: The case of

Michael Du Val's The Spanish English Rose (1622)." SEDERI 22 (2012): 7-27.

Author's contact: leticiaar@us.es

Submission: 07/10/2011_Acceptance: 19/01/2012 